\title{
Exploring the cancer methylome
}

\author{
Benjamin P Berman ${ }^{1}$, Daniel J Weisenberger ${ }^{1}$, Toshinori Hinoue ${ }^{1}$, Houtan Noushmehr ${ }^{1}$, Yaping Liu', \\ Joseph F Aman', Toshinori Hinoue', Hui Shen', Simeen Malik', Swapna Mahurkar', Timothy Triche Jr', \\ Zachary Ramjan', Charles M Nicolet ${ }^{1}$, David Van Den Berg' ${ }^{1}$, Leslie Cope², James G Herman², Stephen B Baylin², \\ Peter W Laird $^{1 *}$
}

From Beyond the Genome 2012

Boston, MA, USA. 27-29 September 2012

Cancer develops not only as a result of genetic mutations and genomic rearrangements, but also as a consequence of numerous epigenetic alterations, including extensive changes in the distribution of DNA methylation throughout the genome. DNA methylation changes contribute directly to cancer by transcriptional silencing of tumorsuppressor genes through promoter CpG island hypermethylation. Broad epigenomic analysis of human tumors can reveal relationships between large numbers of epigenetic events and can provide insight into the mechanisms underlying concerted epigenetic change. Genomic loci targeted by Polycomb Group Repressors in embryonic stem cells, and involved in cellular differentiation, are predisposed to aberrant DNA methylation in cancer cells, suggesting that an epigenetic block to cellular differentiation may sometimes be an initiating event in carcinogenesis. The very strong associations between distinct epigenetic subtypes, such as CpG Island Methylator Phenotypes (CIMP) and specific somatic genetic events, such as $B R A F$ mutation in colorectal cancer and IDH1 mutation in glioblastoma multiforme are consistent with an early role for DNA methylation alterations, providing a favorable cellular context for the subsequent somatic mutation. The analysis of whole methylomes at single-basepair resolution reveals that cancer-associated changes occur differentially across defined regions of the genome associated with the nuclear lamina. It is apparent that epigenomic analysis is essential for a full understanding of the relationship between alterations in the cancer genome and the origin and clinical diversity of individual tumors.

'USC Epigenome Center, University of Southern California, Keck School of Medicine, Los Angeles, CA, USA

Full list of author information is available at the end of the article

\section{Author details}

'USC Epigenome Center, University of Southern California, Keck School of Medicine, Los Angeles, CA, USA. ${ }^{2} J o h n s$ Hopkins School of Medicine, Baltimore, MD, USA.

Published: 1 October 2012

doi:10.1186/1753-6561-6-S6-024

Cite this article as: Berman et al:: Exploring the cancer methylome. BMC Proceedings 2012 6(Suppl 6):O24.
Submit your next manuscript to BioMed Central and take full advantage of:

- Convenient online submission

- Thorough peer review

- No space constraints or color figure charges

- Immediate publication on acceptance

- Inclusion in PubMed, CAS, Scopus and Google Scholar

- Research which is freely available for redistribution
() Bïomed Central
C Biomed Central

(c) 2012 Berman et al; licensee BioMed Central Ltd. This is an Open Access article distributed under the terms of the Creative Commons Attribution License (http://creativecommons.org/licenses/by/2.0), which permits unrestricted use, distribution, and reproduction in any medium, provided the original work is properly cited. 